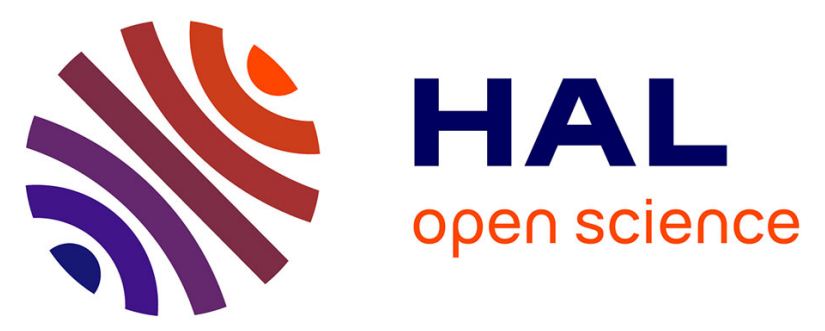

\title{
Clean recovery of antioxidant flavonoids from onions: Optimising solvent free microwave extraction method
}

- Zill-E-Huma, Maryline Vian, Jean Francois Maingonnat, Farid Chemat

\section{To cite this version:}

- Zill-E-Huma, Maryline Vian, Jean Francois Maingonnat, Farid Chemat. Clean recovery of antioxidant flavonoids from onions: Optimising solvent free microwave extraction method. Journal of Chromatography A, 2009, 1216 (45), pp.7700-7707. 10.1016/j.chroma.2009.09.044 . hal-02665436

\section{HAL Id: hal-02665436 https://hal.inrae.fr/hal-02665436}

Submitted on 31 May 2020

HAL is a multi-disciplinary open access archive for the deposit and dissemination of scientific research documents, whether they are published or not. The documents may come from teaching and research institutions in France or abroad, or from public or private research centers.
L'archive ouverte pluridisciplinaire HAL, est destinée au dépôt et à la diffusion de documents scientifiques de niveau recherche, publiés ou non, émanant des établissements d'enseignement et de recherche français ou étrangers, des laboratoires publics ou privés. 


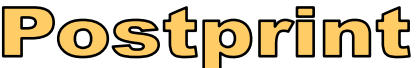

Version définitive du manuscrit publié dans / Final version of the manuscript

published in : Journal of Chromatography A, 2009, DOI: 10.1016/j.chroma.2009.09.044

\section{Clean recovery of antioxidant flavonoids from onions: Optimising solvent free microwave extraction method}

\author{
Zill-e-HUMA, Maryline ABERT-VIAN*, Jean Francois Maingonnat, Farid CHEMAT \\ UMR A408, Sécurité et Qualité des Produits d'Origine Végétale, Université d'Avignon et des \\ Pays de Vaucluse, INRA, F-84000 Avignon, France. \\ Maryline.vian@univ-avignon.fr
}

\begin{abstract}
A solvent free microwave hydrodiffusion and gravity extraction (MHG) of flavonol content from onion (Allium cepa L.) was studied. Effectiveness of this innovative method in extraction of onion total phenolic content, total quercetin (TQ), quercetin aglycon (QA), quercetin-3,4'-diglucoside (QDG), quercetin-4'-monoglucoside (Q4G), quercetin-3monoglucoside $(\mathrm{Q} 3 \mathrm{G})$, kaempferol $(\mathrm{KMF})$ and myricetin (MRT) have been evaluated and compared with conventional solvent extraction. Microwave extraction offers important advantages like shorter extraction time (23 mins), cleaner feature (no solvent or water used) and extraction of valuable onion crude juice retaining fresh organoleptic properties with higher phenolic content (58.29 mg GAE/g DW) at optimized power (500W). Microwave extraction resulted significant yield $(81.5 \%)$ with $41.9 \%$ of flavonol contents, with better retain of remaining flavonoids (55.9\%) in residues of onions. QDG (239.7 mg/100g DW) and Q4G (82.55 mg/100g DW) have been reported the main flavonol in this study. Minor quantities of QA (traces), Q3G (4.22 mg/100g DW) and KMF (3.99 mg/100g DW) were also detected in microwave onion extracts.
\end{abstract}

Keywords: Microwave, extraction, onion, flavonoids, solvent free. 


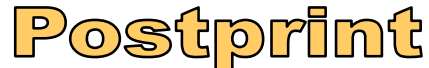

Version définitive du manuscrit publié dans / Final version of the manuscript

published in : Journal of Chromatography A, 2009, DOI: 10.1016/j.chroma.2009.09.044

\section{Introduction}

Human biological system is vulnerable to the attack of extremely reactive oxygen species (ROS), which are produced continuously as a result of endogenous enzymatic reactions and also by exogenous sources $[1,2]$. The formation and activity of these ROS are believed to be responsible for degenerative diseases and their associated complications like cancers, cardiovascular diseases and accelerated aging of organisms [3]. Increased consumption of diets rich in fruits and vegetables are associated with low prevalence of degenerative diseases as they provide a great amount of antioxidant phytochemicals and literature proved antioxidants as one of the defence mechanisms within the organism against ROS [4]. These phenolic antioxidants act as free radical scavengers and offer protection against cellular damage by retarding oxidative stress. Among vegetable polyphenols the flavonoids group generally dominate and found relatively in higher concentration as sugar conjugates as studied by Miean and Mohamed [5] in 62 edible plants and detected abundant amount of quercetin glucosides in different vegetables.

Onion (Allium cepa L.) a versatile vegetable of Allium family is appreciated worldwide not just for its distinctive taste and flavour but also as a significant source of many beneficial compounds. Several studies revealed the presence of various dietary flavonoids in different varieties of onions along with other bioactive compounds [6]. The main flavonol are based on quercetin among which quercetin diglucoside and quercetin monoglucoside are the major components [7-9] and almost all of these are mainly localized in the abaxial epidermis of scales [10]. The amounts of quercetin glucosides are much larger in onion bulbs in comparison with other vegetables $[11,12]$ and they possess very high antioxidative [13] and antiproliferative activities [4]. While considering the usefulness of antioxidants against cardiovascular disease and colorectal cancers, it's necessary to examine their extraction processes from different vegetables for obtaining maximum health effects.

Efficiency of extraction process and mass of release components depend on degree of vegetal cell disintegration which have been achieved previously by conventional solid-liquid extraction, with assistance of processes like heating, boiling, pressing, blending, maceration and mechanical fragmentation of plant material [14-17]. Leaching or organic solvent extraction is the most extensively used process for obtaining plant phenolic components from many decades. Current literature also shows the use of conventional solvent extraction 


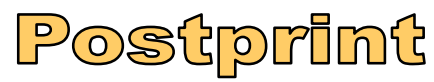

Version définitive du manuscrit publié dans / Final version of the manuscript
published in : Journal of Chromatography A, 2009, DOI: 10.1016/j.chroma.2009.09.044

74

75

supplemented by intensive processes like steam distillation from onion sprouts [18] and Soxhlet extraction of onion peel [3]. Phenolic extracts are also purified and extracted by using ion exchange resins from onion and lettuce $[19,20]$.

Use of these traditional methods not only resulted in degradation of different phenolic contents due to intensive mechanical disruption but the involvement of long extraction timings, severe heating conditions and extensive usage of toxic organic solvents favours the liberation of oxidative enzymes and also promotes these degradation reactions. The use of ultrasound, as an upcoming extraction technique, also has been reported for onion phenolic compounds extraction [21]. The cavitational effect of ultrasound provides greater penetration of solvent into cellular materials which helps in improving the release of cell contents into bulk medium at room temperature, but its main disadvantage is again its extensive requirement of solvents and their incomplete separation from extract.

Microwave hydrodiffusion and gravity (MHG) is a novel technology that has massive potential for variety of extractive applications as the extraction of essential oil have been performed from rosemary leaves [22] and from Spearmint (M. spicata L.) and Pennyroyal (M. pulegiom L.) plant [23]. But for antioxidants extraction, it was the first time we have utilized the efficiency of this innovative technology. The use of microwaves influence textural properties of plant material and increase secondary metabolites diffusion by improving tissue softness and increasing cell permeability. It emerges as an energy saving technology as microwaves are also being able to enhance cell disruption due to their high penetration power resulting in enhancement of mass transfer within and outside the plant tissues [24]. MHG not only appeared as an efficient and economical technology but its chief advantage is its environmental friendly approach as it works without using any solvent just under effect of microwaves and earth gravity at atmospheric pressure [25].

In this case common yellow onion, a vegetable of huge economic importance grown all over the world, loses its water content more rapidly when treated with MHG under controlled temperature. This innovative method proved itself as an ideal alternative extraction method by producing juice with retention of fresh organoleptic qualities and also by retaining increase content of valuable phenolic components. This article illustrates the efficiency of MHG for extraction of flavonoid content of yellow onion at optimized power with combination of control temperature in comparison with conventional solid liquid extraction and also focussed on onion nutritional attributes in terms of total phenol content and flavonol 


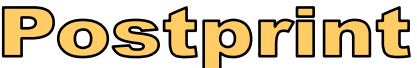

Version définitive du manuscrit publié dans / Final version of the manuscript

published in : Journal of Chromatography A, 2009, DOI: 10.1016/j.chroma.2009.09.044

106

107 contents (total quercetin (TQ), quercetin aglycon (QA) quercetin-3,4'-diglucoside (QDG), quercetin-4'-monoglucoside (Q4G), quercetin-3-monoglucoside (Q3G), kaempferol (KMF) and myricetin (MRT).

\section{Experimental}

\subsection{Raw material}

Raw yellow onions (Allium cepa L.) were purchased from a local supermarket in Avignon province (South France). Onion bulbs which exhibit a diameter of 50-70 $\mathrm{mm}$ and were apparently free of external damages was selected and peeled manually for their following processing.

\subsection{Chemicals}

All solvents used for chromatographic purposes were HPLC grade. Methanol and Formic acid were from Merck (Darmstadt, Germany) and Acetonitrile was from Fisher Scientific Ltd. (Bishop Meadow Road, Loughborough, UK). The HPLC grade flavonol standards quercetin3,4'-diglucoside and quercetin-4'-glucoside (spiraeoside) were purchased from Extrasynthese (Lyon, France). Quercetin, quercetin-3-glucoside, kaempeferol and myricetin were purchased from Sigma Chemicals Chimie (Fallavier, France).

\subsection{Determination of moisture content}

Moisture content determination of onion was carried out firstly by conventional DeanStark distillation apparatus according to the American Oil Chemist' society (AOCS) official method [26], and also with an electric oven at $80^{\circ} \mathrm{C}$. The average moisture content measured by both processes was $88.5 \pm 0.5 \%$.

\subsection{MHG apparatus and procedure}

Microwave hydrodiffusion and gravity has been performed in a Milestone EOS-G microwave laboratory oven illustrated in Fig. 1. This is a multimode microwave reactor 2.45 $\mathrm{GHz}$ with a maximum delivered power of $900 \mathrm{~W}$ variable in $10 \mathrm{~W}$ increments. Time, temperature, pressure and power can be controlled with the "easy-WAVE" software package. The extraction vessels are made from Pyrex and have a capacity of $1000 \mathrm{~mL}$. During experiments temperature was monitored by temperature sensor optic fibers which were 


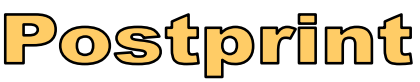

Version définitive du manuscrit publié dans / Final version of the manuscript
published in : Journal of Chromatography A, 2009, DOI: 10.1016/j.chroma.2009.09.044

136 inserted in the centre and outer layer of sample and also in the sample reactor. Temperature 137 variations in different parts of plant material and reactor were measured continuously and data 138 was saved automatically. This feedback helped in controlling the temperature by microwave 139 power regulator.

\subsection{Conventional solid liquid extraction}

In conventional solid liquid extraction fresh onion scales were used, onion bulb was peeled and cut manually and $5 \mathrm{~g}$ onion scales were homogenised with $50 \mathrm{~mL}$ of $80 \%$ methanol in an ultrahomogeniser at $8000 \mathrm{rpm}$ for $45 \mathrm{mins}$. After that the mixture was filtered and supernatant was collected and made upto $50 \mathrm{~mL}$ of methanol. This filtered solution was used directly for HPLC and TPC analysis. Final concentrations of different flavonoids were calculated in mg/100g DW (dry weight).

\subsection{HPLC analysis}

HPLC analyses were performed using a Waters (Milford, MA) HPLC system consisting of a Waters 600E pump, a Waters 717 manual injector rheodyn, a Waters 2996 photodiode array detector. The HPLC pumps, manual injector rheodyn, column temperature, and diode array system were monitored and controlled by using Waters Empower 2 Chromatography Data software program. The wavelength used for the quantification of the onion flavonoids with the diode detector was $360 \mathrm{~nm}$. The chromatographic separation was carried out on a Purospher Star RP-18 end-capped column $(250 \mathrm{~mm} \times 4 \mathrm{~mm}$ I.D.; $5 \mu \mathrm{m}$ particle size from VWR), with a RP18 guard column (4 $\mathrm{mm} \times 4 \mathrm{~mm}$ I.D.; $5 \mu \mathrm{m}$ particle size also from VWR). The end-capped column and guard column were held at $37^{\circ} \mathrm{C}$ and the flow rate 


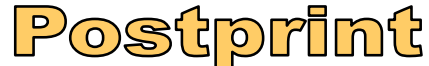

Version définitive du manuscrit publié dans / Final version of the manuscript

published in : Journal of Chromatography A, 2009, DOI: 10.1016/j.chroma.2009.09.044 was set at $1 \mathrm{~mL} / \mathrm{min}$. The mobile phase consisted of two solvents: (A) acidified water $(0.5 \%$ formic acid) and (B) 100\% acetonitrile. The solvent gradient used was the following: 0 min, (A) $95 \%$ and (B) 5\%; 20min, (A) $60 \%$ and (B) 40\%; 30min, (A) $0 \%$ and (B) 100\%; 45min, (A) $95 \%$ and (B) $5 \%$. The injection volume was $20 \mu \mathrm{L}$ and all analyses were performed at least three times and only mean values were reported. Identification of flavonoids was done by comparing the elution order and UV-visible spectra. Quantification was carried out by using the external standards of known concentration. Peak areas were used to quantify the compounds in the sample. A linear regression analysis was carried out on the data of the peak area versus concentration. Linear calibration curves of the standards ranging from 10 to 100 $\mathrm{mg} / \mathrm{L}$ were obtained with good linearity and $\mathrm{R}^{2}$ values which were more than $99.5 \%$ accurate for all the standards. Extraction was performed three times and final concentrations of different flavonoids were calculated by using the mean values, expressed in $\mathrm{mg} / 100 \mathrm{~g} \mathrm{DW}$.

\subsection{Total phenolic content (TPC)}

Total polyphenols were estimated colorimetrically using the Folin-Ciocalteu method [27], with a kit (SEPPAL (Isitec-lab), France) especially suitable for TPC measurement of food products. This kit includes reagent A (modified Folin-Ciocalteu reagent), reagent B (alkaline buffer) and a gallic acid solution (3g/L). A small volume (20 $\mu \mathrm{L})$ of $\mathrm{H}_{2} \mathrm{O}$ (blank), gallic acid solution (standard) and $200 \mu \mathrm{L}$ the extract (sample) was mixed with reagent A (2 $\mathrm{mL}$ ). After $1 \mathrm{~min}, 1 \mathrm{~mL}$ of reagent $\mathrm{B}$ was added in both water and gallic acid standard and $850 \mu \mathrm{L}$ in sample. The mixtures were allowed to stand for $30 \mathrm{~min}$ in the dark at room temperature. Then, their absorbance was measured at $760 \mathrm{~nm}$ with a diode-array HewlettPackard 8453 spectrophotometer [28]. TPCs were calculated by using the following formulae: TPC $=3 \times$ (sample absorbance - blank absorbance) / (standard absorbance - blank absorbance). TPC measurements were performed thrice and mean values, expressed as mg gallic acid equivalent/g of dry weight (mg GAE/g DW), were reported.

\section{Results and discussion}

Efficient performance of MHG for onion antioxidants extraction depends on different factors like moisture of plant material, irradiation power, temperature and time. To determine optimal reaction conditions for obtaining significant results a preliminary study consisting of various experiments was carried out. 


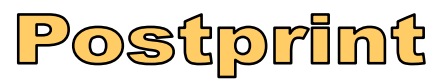

Version définitive du manuscrit publié dans / Final version of the manuscript

published in : Journal of Chromatography A, 2009, DOI: 10.1016/j.chroma.2009.09.044

\subsection{Microwave heating phenomenon}

Fig. 2 shows the heating phenomenon proceeding in the centre of onions at different powers from $300 \mathrm{~W}-900 \mathrm{~W}$ detected by temperature sensor optic fibre. Different phases in development of temperature can be distinguished (Fig. 2). The first phase corresponds to the heating phase (A), a rapid increase in temperature was observed from initial temperature $\left(20^{\circ} \mathrm{C}\right)$ of onions to the boiling point of water $\left(100^{\circ} \mathrm{C}\right)$. Heating rates observed in this phase were proportional to the different applied powers: $8.5^{\circ} \mathrm{C} / \mathrm{min}(300 \mathrm{~W}), 13.5^{\circ} \mathrm{C} / \mathrm{min}(400 \mathrm{~W})$, $29.7^{\circ} \mathrm{C} / \mathrm{min}$ (500W), $32.2^{\circ} \mathrm{C} / \mathrm{min}(600 \mathrm{~W}), 36^{\circ} \mathrm{C} / \mathrm{min}$ (700W), $40^{\circ} \mathrm{C} / \mathrm{min}$ (800W) and $45.9^{\circ} \mathrm{C} / \mathrm{min}(900 \mathrm{~W})$. During this phase, in situ water of plant material was heated up, when irradiated with microwaves and diffused out of plant material and moved downward under the influence of earth gravity. This phase was ended with appearance of first drop of water outside the microwave cavity.

At this point, temperature maintained to a plateau region and remained in this steady state at $100^{\circ} \mathrm{C}$ until the complete extraction of non bounded water. It corresponds to the extracting phase (B) of process, and when there was only tightly bound water remained, the temperature increased very quickly and led to the burning phase $(\mathrm{C})$ which leads to the end of extraction. Heating rates of burning observed at different powers during this phase were: $5.14^{\circ} \mathrm{C} / \mathrm{min}(300 \mathrm{~W}), 6^{\circ} \mathrm{C} / \mathrm{min}(400 \mathrm{~W}), 8.5^{\circ} \mathrm{C} / \mathrm{min}(500 \mathrm{~W}), 9.6^{\circ} \mathrm{C} / \mathrm{min}(600 \mathrm{~W}), 10.3^{\circ} \mathrm{C} / \mathrm{min}$ (700W), $12^{\circ} \mathrm{C} / \mathrm{min}(800 \mathrm{~W})$ and $16.4^{\circ} \mathrm{C} / \mathrm{min}(900 \mathrm{~W})$. Here, we can observe that the initial heating rates were more rapid than the heating rates of burning. Perhaps, it was due to the less free water content, inside the onion during the last phase of heating.

Similar phases were also detected by using optic fibers in outer layer of onion and also in reactor but the heating efficiency were in descending order from centre to outer layer of onion and then the reactor. Heating rates of phase $\mathrm{A}$ and phase $\mathrm{C}$ observed in the outer layer of onion and also in reactor were proportional to the applied powers but were less quick in comparison to the rates observed in centre of onion. Behind this, heating phenomenon of microwaves works, which are distributed volumetrically and heat transfer occurs from centre of samples to the outer colder environment. This cause an important difference when compared to conventional heating in which heat transfer occurs from outer layer to centre of onion (Fig. 2). While considering the mass transfer, it occurs from inside to the outside of plant material both in microwave and conventional heating [29]. In conventional heating, heat transfer depends on thermal conductivity, on the temperature difference across the sample, 


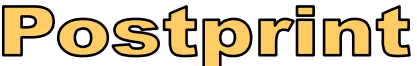

Version définitive du manuscrit publié dans / Final version of the manuscript

published in : Journal of Chromatography A, 2009, DOI: 10.1016/j.chroma.2009.09.044

228 and for fluids on convection currents. As a result, the temperature increase is often rather 229 slow. By contrast, in microwave heating, due to volumetric heating effect, much faster temperature increases can be obtained, depending on microwave power and the dielectric loss factor of the material being irradiated.

\subsection{Extraction kinetics}

In order to carry out the study on extraction kinetics of onion extracted juice, volume of onion juice obtained at different powers was plotted as function of time. Extraction curves obtained at different powers in Figure 3 shows three diverse stages of extraction.

Stage 1 corresponds to the induction time, during this phase no recovery of water was occurred. It ends with emergence of first water drop.

Stage 2 represent the constantly increasing flow rate of extract as illustrated in Figure 3 by linear curves at different powers. All the easily exchangeable water of onion was extracted in this phase. During this phase the gradient of curves increases with increase of power.

Stage 3 marks the end of extraction process as represented by horizontal line on graph. At initiation of this phase, onions were almost dry with no more further extraction. At this point, burnt smell was generated as a result of prolonged heating.

Finally, the extracted crude juice was collected freeze dried and yield was expressed in percentage $(\%)$.

\subsection{Extraction yield}

The aim of this part of study was to examine the impact of MHG on extraction yield of crude onion juice at various powers. Actual yield of four medium sized onions was taken until the time at which moisture collection was completely stopped due to overheating. No remarkable difference in onion juice yield was observed at different powers. A slight decrease in juice volume was observed while moving from lower $(300 \mathrm{~W})$ to higher $(900 \mathrm{~W})$ power. The percentage of crude juice yields calculated at different powers was: $82.7 \%$ (300W), $82.1 \%$ (400W), 81.5\% (500W), 81.1\% (600W), 80.8\% (700W), 80.3\% (800W) and 79.7\% (900W), which is close to the actual moisture percentage (88.52\%) of fresh onion. 


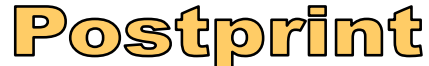

Version définitive du manuscrit publié dans / Final version of the manuscript

published in : Journal of Chromatography A, 2009, DOI: 10.1016/j.chroma.2009.09.044

The water content of onion is not an alone factor for determining the final yield. The onion crude juice also holds some soluble compounds like sugar, acids and polyphenols. The dry extracts weight which was taken, after removal of water content of crude onion juice by the process of freeze drying, at different powers was also in descending order from lower to higher powers. The weight of dry extracts yields we obtained at different powers, $4.70 \%$ (300W), 4.40\% (400W), 4.28\% (500W), 3.41\% (600W), 2.87\% (700W), 2.19\% (800W) and $1.95 \%(900 \mathrm{~W})$, proved that the efficient extraction of soluble solids significantly depends on applied powers. As it vary remarkably among very lower and very high power.

\subsection{Microwave extracted onion polyphenol contents}

\subsubsection{Total phenolic content}

The amount of total phenolic content (TPC) varied in the onion extracts obtained at different powers as shown in Table 1. Highest phenolic content (58.29 mg GAE/g DW) was found at power of $500 \mathrm{~W}$ and lowest content was observed at $900 \mathrm{~W}$ (29.94 mg GAE/g DW). Initially TPC increased with increase of power from $300 \mathrm{~W}$ (47.54 mg GAE/g DW), and a maximum amount was detected at 500W but with further increase of power, phenolic content concentration started to decrease and lowest concentration was observed at very high power (900W). TPC results obtained at 500W were not only significant in comparison with conventional solvent extraction (64.81 $\mathrm{mg} \mathrm{GAE} / \mathrm{g} \mathrm{DW})$ but also correlate with previous data. Our detected range of TPC falls in the range (4.6-74.1 mg GAE/g DW) observed in different varieties and layers of Allium cepa, including varieties contain very high level of phenolic content (red onion) to very low level (white onion) [30]. These results are also found in good concentration in comparison to the TPC values studied by Nuutila et al. [31] in the dry outer skin of red (80.0 mg GAE/g) and yellow onions (26.0 mg GAE/g). TPC values of microwave extracted (at 500W) residue was also observed after its conventional solvent extraction, in order to check the remaining amount of phenolic contents in residue, which was $21.60 \mathrm{mg}$ GAE/g DW, these results shows that with MHG we have extracted a good percentage of phenolic compounds along with "in situ" water content of plant material.

\subsubsection{Flavonoid content of onion extracts obtained at different powers}

\subsubsection{Total quercetin and major flavonoids}




\section{PంS\{็}

Version définitive du manuscrit publié dans / Final version of the manuscript

published in : Journal of Chromatography A, 2009, DOI: 10.1016/j.chroma.2009.09.044

Total quercetin presented in Table 1 is the sum of concentration of free quercetin and different forms of quercetin present in conjugation with carbohydates mainly as glucosides like QDG, Q4G and Q3G. QDG and Q4G provide a good estimation of level of total quercetin in the sample as they are representing about $90 \%$ of overall flavonol content [32]. QDG was detected in highest concentration in comparison to other quercetin glucosides followed by Q4G identified as second major flavonol compound. Quantification of all these compounds has been done by comparing the retention time and absorbance of peaks at 360nm with the use of authentic standards. In preliminary study, extraction efficiency of different powers for flavonol contents was tested. Higher levels of total quercetin $(326.5 \mathrm{mg} / 100 \mathrm{~g} \mathrm{DW})$ was calculated at 500W (Table 1) compared to other applied powers, which correspond well to the previous published data $(414 \mathrm{mg} / 100 \mathrm{~g}$ DW found by Aoyama andYamamoto [14] in yellow onion; $348 \mathrm{mg} / 100 \mathrm{~g}$ DW quercetin content in yellow onion illustrated in Danish results by Justesen et al. [33], $507 \mathrm{mg} / 100 \mathrm{~g}$ DW by Hertog et al. [11] and $280 \mathrm{mg} / 100 \mathrm{~g}$ DW by Mogren et al, [34] ). All the analyzed flavonols have shown almost similar behaviour to TQ, as the highest levels of QDG (239.7 mg/100g DW) and Q4G (82.55 mg/100g DW) were also found at 500W. These results not only fall in the range reported by Cardi et al. [32], (QDG: 153-404 mg/100g DW, Q4G: 58-286 mg/100g DW) among different onion varieties but Q4G was also found in good concentration as compared to the results determined by Roldán-Marín et al. [9] (282 mg/100g DW concentration of QDG and $43.9 \mathrm{mg} / 100 \mathrm{~g}$ DW of Q4G) in high pressure processed onion. Bonaccorsi et al. [8] have also found QDG in highest concentration in red onion variety $(254-274 \mathrm{mg} / 100 \mathrm{~g}$ DW), our results also correspond well with these results as yellow onion ranked after red onion as a good source of quercetin flavonoid contents. Concentration of QDG (581.8 mg/100g DW) and Q4G (187.5 mg/100g DW), in fresh onion samples treated with conventional solvent extraction was also detected in higher amount in comparison to other flavonols. TQ concentration determined by conventional solvent extraction method was $782.6 \mathrm{mg} / 100 \mathrm{~g}$ DW which falls in the range of flavonols content of yellow onion (270-1187mg/100g DW) reviewed by Slimestad et al. [35]. For analysing the effect of microwave on stability of flavonoid content and their extraction efficiency, concentration of flavonoids retained in microwave extracted (at 500W) onion samples was also calculated by conventional solvent extraction. TQ retained in the residue of microwave extracted onions was found $440.7 \mathrm{mg} / 100 \mathrm{~g}$ DW which is $56 \%$ of the TQ content determined by conventional solvent extraction of fresh onion. Amount of TQ observed at $500 \mathrm{~W}$ is $42 \%$ of the concentration determined by conventional method. Our results showed $2 \%$ losses of TQ by microwave extraction in comparison to conventional fresh onion 


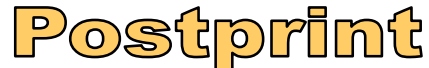

\section{Version définitive du manuscrit publié dans / Final version of the manuscript published in : Journal of Chromatography A, 2009, DOI: 10.1016/j.chroma.2009.09.044}

extraction. Concentration of major flavonols, QDG (342.4 mg/100g DW) and Q4G (95.2 $\mathrm{mg} / 100 \mathrm{~g} \mathrm{DW}$ ), retained in residue of onions was found almost comparable with microwave extracted content along with water content of onions. These results showed that there was no remarkable loss or degradation of flavonoid compounds occurred at $500 \mathrm{~W}$ and onion bulbs still retained a good amount of these major compounds after microwave extraction of water content. Similar to the findings of Rodrigues et al. [36], as they have been determined no loss of QDG and Q4G at mild (450W) microwave heating in comparison to untreated onion but 16\% (QDG) and 18\% (Q4G) losses were detected with increase of power (750W). Similarly, losses of these compounds were also observed with increase of power, in comparison to the highest concentration observed at 500W. A rapid decrease in concentration was observed at intense powers as shown in Table 1 and finally lowest amount of QDG was determined at 900W (101.6 mg/100g DW) with complete absence of detectable amount of Q4G, as more intense treatments resulted with loss of quercetin components. But very low power (300W) was also not an effective and efficient power for flavonoids extraction, along this it also consumes more time for complete extraction of onion water content. QDG exhibited the lowest loss (degradation or conversion into quercetin aglycon) as it is still present at very drastic condition at $900 \mathrm{~W}$ in comparison to Q4G, Q3G and free quercetin which were not detected at 900W. In QDG glucose is attached at 3 and $4^{\prime}$ and due to blockage of the two positions it showed much greater stability then $\mathrm{Q} 4 \mathrm{G}$ in which position 3 is not conjugated. Makris and Rossiter [37] have also observed the lowest loss in QDG concentration (8.4\%) and Q4G and QA content declined by 37.6\% when subjected to heating treatments. Our results are also supported by the work of Kana et al. [38] who has selected microwave roasting without water as a better cooking method to retain flavonoids in onion tissue. But the concentration of TQ varied with power. This shows that microwave with a mild power is an efficient method for extraction of quercetin components without remarkable degradation. With MHG we can extract more than $40 \%$ of the flavonol components along with the "in situ" water content of onions also possessing fresh organoleptic properties.

\subsubsection{Minor flavonoids}

Free quercetin was also quantified in conventional and microwave extracted samples at retention time of $24.352 \mathrm{~min}$ by HPLC. The content of free quercetin showed a low percentage in comparison with QDG and Q4G. Any measurable quantity of QA was not detected at low powers $300 \mathrm{~W}$ and $400 \mathrm{~W}$. At 500W just traces of QA were observed, similar 


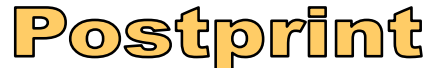

\section{Version définitive du manuscrit publié dans / Final version of the manuscript published in : Journal of Chromatography A, 2009, DOI: 10.1016/j.chroma.2009.09.044}

353

354

to the results obtained by Patil et al. [39] in four yellow onion varieties and one pink and red onion variety. They have detected not more than $0.4 \mathrm{mg} / 100 \mathrm{~g} \mathrm{DW}$ of free quercetin in all the onions. Zielinska et al. [40] also mentioned only $1.1 \%$ of free quercetin in yellow onion bulbs. At $600 \mathrm{~W}$ a good concentration $(5.25 \mathrm{mg} / 100 \mathrm{~g}$ DW) of QA was detected but then a fall in concentration was observed with increase of power. In fresh onions normally there is always a low concentration of QA but as a result of some treatment or processing breakdown of glycosidic bonds in QDG and QMG, a good concentration of QA can be detected. Perhaps similar is the case here with decrease of qercetin glycosidic forms, an increase in concentration of QA observed at high powers of $600 \mathrm{~W}$ and $700 \mathrm{~W}$. But with further increase of power, phenomenon of degradation was more profoundly expressed in free quercetin which has both sides exposed. With conventional solvent extraction method ( $80 \%$ methanol) a very light concentration of QA was observed $(1.32 \mathrm{mg} / 100 \mathrm{~g} \mathrm{DW})$ and in the residues we have also detected just traces of QA.

Along with QA the other minor components which are representing almost less than $5 \%$ of total amount of flavonols were analysed. Very small peaks with retention times of 18.115min and 27.289min have been identified as Q3G and kaempferol, respectively, by comparison with their standards. Similar to the already discussed major compounds highest concentration of Q3G have been detected at $500 \mathrm{~W}(4.22 \mathrm{mg} / 100 \mathrm{~g} \mathrm{DW})$ which is almost $1.27 \%$ of the total amount of analysed flavonols. This value is in good agreement with the results of Zielinska et al. [40] who have determined $1.4 \%$ of Q3G in Sochaczewska onion variety which is a typical onion with a yellow-brown bulb colour. Similar to other flavonoids, it was also detected in minor amounts at vary high powers.

Kaempferol presence in comparison to quercetin content in different varieties of onions has been reported in minor quantities [39]. Kaempferol content identified and quantified at 400W (4.01mg/100g DW) and 500W (3.99mg/100g DW) were not significantly different from each other, and these values were similar to the previously reported values of 3-7 $\mathrm{mg} / 100 \mathrm{~g}$ DW by Bilyk et al.[41] in the outer and inner skins of bulbs of different varieties. A slightly higher content of kaempferol has been reported by Sellappan and Akoh [42] in five varieties of onion which ranged from $15.4-19.8 \mathrm{mg} / 100 \mathrm{~g} \mathrm{DW}$. In contrast to the findings of Sellappan and Akoh [42], myricetin was not detected in yellow onion variety which we have extracted and analysed. The presence of different flavonoids varied among 


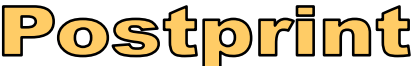

Version définitive du manuscrit publié dans / Final version of the manuscript

published in : Journal of Chromatography A, 2009, DOI: 10.1016/j.chroma.2009.09.044

384

385

different varieties and their concentration also depends on different factors like climatic conditions and stages of maturity.

\subsubsection{Flavonoid contents at optimized power}

Impact of different microwave irradiation powers, from 300W-900W, were examined in terms of heating and burning rate, yield, extraction rate, flavonoid contents. With increasing power no better results were obtained, as at high powers (600W-900W), high speed of extraction was observed but resulted with less total dry extract yield due to degradation of phenolic compounds. On the other hand low power resulted more yield but with slower extraction rate and are also inefficient for complete extraction of flavonoids. An irradiation power of $500 \mathrm{~W}$ was selected as an optimum power for later experiments. At optimized power, the yield and flavonoids composition were examined after each five minutes $(\mathrm{A}=0-3 \min , \mathrm{B}=3-8 \min , \mathrm{C}=8-13, \mathrm{D}=13-18, \mathrm{E}=18-23, \mathrm{~F}=23-27.5)$.

Initially, in situ water was heated at the rate of $27.9^{\circ} \mathrm{C} / \mathrm{min}$ and it takes almost $3 \mathrm{mins}$ (A) to reach the extraction temperature $100^{\circ} \mathrm{C}$, resulted with appearance of first drop. Almost comparable yields of water content were obtained after each five minutes: $14.7 \%$ (B), 17.6\% (C), $16.9 \%(\mathrm{D}), 16.4 \%(\mathrm{E})$, and $15.9 \%(\mathrm{~F})$, until the end of extraction process completed in 27.5 mins. But the dry extract yield obtained after freeze drying was in inverse proportion to the time, as with increase of time, the percentage of extracted component decreased (Fig 4). Highest yield of flavonoid components obtained in part C: QDG (108.5mg/100g DW), Q4G (41.9mg/100g DW), Q3G (1.80mg/100g DW). Traces of QA were also detected only in part $\mathrm{C}$ which also showed the highest content of total phenols (20.1 mg GAE/g DW) in comparison to other parts of extraction process: $18.9 \mathrm{mg}$ GAE/g DW (B), 16.1mg GAE/g DW (D) and 15.9mg GAE/g DW (E). Highest dry extract yield was observed in part B as shown in Figure 4. but the lower content of flavonoids were observed in this part in comparison to part $\mathrm{C}$; QDG (89.18mg/100g DW), Q4G (30.9mg/100g DW), Q3G (1.74mg/100g DW). After part C the next extracted parts D and E resulted with further decrease in dry extract yield with minimum content of flavonoids. In part $\mathrm{D}$ only the two major components: QDG (44.6mg/100g DW) and Q4G (7.16mg/100g DW) were detected. Kaempferol was detected in part $\mathrm{E}$ of extraction along with minimum quantity of these above mentioned major flavonoid components QDG (16.4mg/100g DW) and Q4G (1.12mg/100g DW). Onion juice extracted in first 23mins just before the onset of burning was analysed with HPLC (Fig. 5) and rejected 


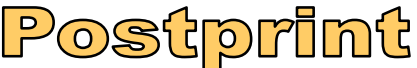

Version définitive du manuscrit publié dans / Final version of the manuscript

published in : Journal of Chromatography A, 2009, DOI: 10.1016/j.chroma.2009.09.044

415 the last part of juice which was extracted during burning, as the content of flavonoids have 416 already been decreased.

\subsection{Cost, cleanliness and scale-up of the method}

The reduced cost of extraction is clearly advantageous for the proposed MHG method

\section{Conclusion and perspectives} in terms of time and energy. Conventionnal solvent extraction required sorganic solvent, long extraction time, evaporation of the solvent is needed and the purification of the extract. The MHG method required irradiation for $20 \mathrm{~min}$ only. MHG is proposed as an "environmentally friendly" extraction method which avoids the use of large quantities of solvent and voluminous extraction vessels.

MHG could also be used to produce larger quantities of extracts by using existing large-scale microwave extraction reactors (www.archimex.com). These microwave reactors are suitable for the extraction of 10,20 , or $100 \mathrm{~kg}$ of fresh plant material per batch. These reactors could be easily modified and used for MHG isolations.

MHG is a novel technology which has been used first time for extraction of onion flavonol content, whose antioxidant activity relates to human health promoting effects. With MHG its possible to extract $330.46 \mathrm{mg}$ of flavonol content from one kilo gram of fresh plant material (yellow onion variety), which is $41.9 \%$ of the flavonoid content extracted with solvent (80\% methanol) from fresh plant material, along with crude onion juice content retaining organoleptic properties similar to fresh unprocessed product. MHG is an attractive novel technology that clearly offers opportunities for food processing industries to meet the growing demand of consumers for healthier food products as it works in absence of any solvent. Along with paying its role in creation of green environment, this technique is also offering a quicker alternative extraction process which allows substantial saving in energy and cost.

\section{References}

[1] D. Stajner, I.S. Varga, Acta. Bio. Szegediensis. 47(2003)103. 


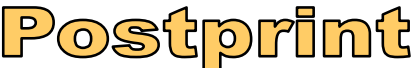

Version définitive du manuscrit publié dans / Final version of the manuscript published in : Journal of Chromatography A, 2009, DOI: 10.1016/j.chroma.2009.09.044

446 [2] B. Subhasree, R. Basker, R.L. Keerthana, R.L. Susan, P. Rajasekaran, Food Chem. $447 \quad 115(2009) 1213$.

[3] B.N. Singh, B.R. Singh, R.L. Singh, D. Prakash, D.P. Singh, B.K. Sarma, G. Upadhyay, H.B. Singh, Food. Chem Toxi. 47(2009)1161.

[4] D. Boivin, S. Lamy, S. Lord-Dufour, J. Jackson, E. Beaulieu, M. Côté, A. Moghrabi, S. Barrette, D. Gingras, R. Béliveau, Food Chem. 112(2009)374.

[5] K.H. Miean, S. Mohamed, J. Agric. Food Chem. 49(2001)3106.

[6] J. Lachman, D. Proněk, A. Hejtmánková, J. Dudjak, V. Pivec, K. Faitová, Horti Sci. 454 4(2003)142.

455 [7] M.J.C. Rhodes, K.R. Price, Food Chem. 57(1996)113.

[8] P. Bonaccorsi, C. Caristi, C. Gargiulli, U. Leuzzi, Food Chem. 107(2008)1668.

[9] E. Roldán-Marín, C. Snchez-Moreno, R. Lioría, B.D. Ancos, M.P. Cano, LWT-Food Sci. 458 Tech. 42(2009)835.

459 [10] S. Hirota, T. Shimoda, U. Takahama, Food Sci. Tech.5(1999)384.

460 [11] M.G.L Hertog, P.C.H., Hollman, D.P. Venema, D.P. J. Agric. Food Chem. 461 40(1992)1591.

462 [12] S. Gorinstein, H. Leontowicz, M. Leontowicz, J. Namiesnik, K. Najman, J. Drzewiecki, 463 M. Cvikrová, O. Martincová, S. Trakhtenberg, J. Agric. Food Chem. 56(2008)4418.

[13] P. Stratil, B. Klejdus, V. Kubán, , J. Agric. Food Chem. 54(2006)607.

465 [14] S. Aoyama, Y. Yamamoto, Food Sci. Tech. 13(2007)67.

466 [15] J. Yang, K.J. Meyers, J.V.D. Heide, R.H. Liu, J. Agric. Food Chem. 52(2004)6787.

467 [16] U. Takahama, T. Oniki, S. Hirota, J. Plant. Res. 114(2001)395.

468 [17] T. Sun, J.R. Powers, J. Tang, Food Chem. 105(2007)101. 


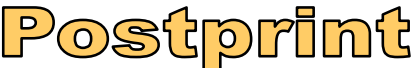

Version définitive du manuscrit publié dans / Final version of the manuscript

published in : Journal of Chromatography A, 2009, DOI: 10.1016/j.chroma.2009.09.044

469 [18] M. Takahashi, T. Shibamoto, J. Agric. Food Chem. 56(2008)10462.

470 [19] T.N. Ly, C. Hazama, M. Shimoyamada, H. Ando, K. Kato, R. Yamauchi, J. Agric. Food 471 Chem. 53(2005)8183.

472 [20] P. Goupy, M. Amiot-Carlin, J. Escudier, M. Mikolajczak, M. Martin, US Pat. 6,824,797 473 B2, 2004.

[21] J. Santas, R. Carbó, M.H. Gordon, M.P. Almajano, Food Chem. 107(2008)1210.

[22] N. Bousbia, M. Abert-Vian, M.A. Ferhat, B.Y. Meklati, F. Chemat, J. Food. Eng. 90 476 (2009)409.

[23] M. Abert-Vian, X. Fernandez, F. Visinono, F. Chemat, j. Chromatogr. A. 1190 (2008) 14.

[24] F. Chemat, M. Lucchesi, Microwave-assisted extraction of essential oils, in Microwaves in organic synthesis, A. Loupy (ed) Weinheim, 2006, pp.

[25] F. Chemat, M. Abert-Vian, F. Visinoni, EP 1955749 A1,(2008).

[26] Official Method Ja 2a-46, American Oil Chemist Society, Champaign, IL, 1993.

[27] J.A. Vinson, B.A. Hontz, J. Agric. Food Chem. 43(1995)401.

[28] C. Dufour, M. Loonis, O. Dangles, Free Radical. Bio Med. 43(2007)241.

[29] S. Veillet, V. Tomao, F. Visinoni, F. Chemat, Anal. Chim. Acta. 632(2009)203.

[30] D. Prakash, B.N. Singh, G. Upadhyay, Food Chem. 102(2007)1389.

[31] A.M. Nuutila, R. Puupponen-Pimiä, M. Aarni, K. Oksman-Caldentey, Food Chem. 81(2003)485.

[32] D. Caridi, V.C. Trenerry, S. Rochfort, S. Duong, D. Laugher, R. Jones, Food Chem.105 490 (2007)691.

491 [33] U. Justesen, P. Knuthsen, T. Leth, J. Chromatogr. A. 799(1998)101. 


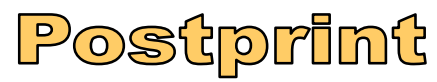

Version définitive du manuscrit publié dans / Final version of the manuscript

published in : Journal of Chromatography A, 2009, DOI: 10.1016/j.chroma.2009.09.044

492 [34] L.M. Mogren, M.E. Olsson, U.E. Gertsson, J. Chromatogr. A. 1190(2006)14.

493 [35] R. Slimestad, T. Fossen, I.M. Vagen, J. Agric. Food Chem. 55(2007)10067.

494 [36] A.S. Rodrigues, M.R. Pérez-Gregorio, M.S. García-Falcón, J. Simal-Gándara, Food Res. 495 Inter(2009), Article in Press.

496 [37] D.P. Makris, J.T. Rossiter, J. Agric. Food Chem. 49(2001)3216.

497 [38] I. Kana, A. Yuka, T. Ayaka, T. Junji, N. Nobuji, T. Yoko, J. Nutri Sci. Vita.47 (2001)78.

498 [39] B.S. Patil, L.M. Pike, K.S. Yoo, J. Ameri Soc. Horti Sci. 120(1995)909.

499 [40] D. Zielinska, W. Wiczkowski, M.K. Piskula, J. Agric. Food Chem. 56(2008)3524.

500 [41] A. Bilyk, P.L. Cooper, G.M. Sapers, J. Agric. Food Chem. 32 (1984)274.

501 [42] S. Sellappan, C.C. Akoh, J. Agric. Food Chem. 50(2002)5338. 